\title{
Expression of Eukaryotic Membrane Proteins in Pichia pastoris
}

\author{
Lucie Hartmann ${ }^{1}$ \\ Valérie Kugler \\ Renaud Wagner 1 , \\ Email renaud.wagner@unistra.fr \\ Biotechnology and Cell Signalling, IMPReSs Protein Facility, UMR7242 ESBS \\ CNRS, University of Strasbourg, 300 Blvd S. Brant, 67412 Illkirch, France
}

\section{AQ1}

\begin{abstract}
A key point when it comes to heterologous expression of eukaryotic membrane proteins (EMPs) is the choice of the best-suited expression platform. The yeast Pichia pastoris has proven to be a very versatile system showing promising results in a growing number of cases. Indeed, its particular methylotrophic characteristics combined to the very simple handling of a eukaryotic microorganism that possesses the majority of mammalian-like machineries make it a very competitive expression system for various complex proteins, in amounts compatible with functional and structural studies. This chapter describes a set of robust methodologies routinely used for the successful expression of a variety of EMPs, going from yeast transformation with the recombinant plasmid to the analysis of the quality and quantity of the proteins produced.
\end{abstract}

\section{Keywords}

\section{Pichia pastoris}

Yeast

Eukaryotic membrane protein

GPCR

Heterologous expression

\section{Introduction}

Pichia pastoris is one of the few budding yeasts that have developed a specific methanol utilization metabolism. Upon deprivation of preferential carbohydrates (i.e., sugars, glycerol), the presence of methanol as the unique carbon source actually strongly stimulates the expression of genes involved in its degradation for energy and biomass production [1]. The exceptional expression levels triggered by these tightly regulated methanol-dependent promoters have thus been exploited to constitute one of the most efficient eukaryotic systems used for bioproduction purposes. Up to now indeed, hundreds of proteins have been successfully produced with this host, including more than 70 commercial products ( http://www.pichia.com/science-center/commercialized-products ).

Non-surprisingly, this system has also proven to be very powerful for the recombinant expression of 
a large number of eukaryotic membrane proteins (EMPs) from various key membrane functions (transport, signaling, enzymatic activities) and diverse structural organizations (representative membrane-spanning topologies and oligomeric states involving various membrane and cytosoluble subunits). As a strong illustration of its versatility and competitiveness in this domain, the most diverse panel of structure-solved EMPs has been produced with P. pastoris, encompassing P-glycoprotein ABC transporters, monoamine oxidases, G-protein-coupled receptors (GPCRs), several aquaporins, and various types of ion channels ( http://blanco.biomol.uci.edu/mpstruc/ , as of June 2015).

A full description of the system, its advantages and drawbacks, and how it performs for the production of EMPs in comparison with other expression systems can be found in a number of very complete and authoritative reviews [2-6].

We present here a series of robust and straightforward methodologies and techniques that we routinely apply for the overexpression of EMPs that are intended to be purified for different biochemical and biophysical purposes [7-10]. Exemplified with a panel of representative EMPs, this chapter covers all the procedures needed to handle the expression system, from yeast transformation and clone selection steps down to the inducible expression phases in different formats. Associated analytical experiments performed to evaluate the expression levels and, when possible, the activity of the recombinant EMP, are also described. The following extraction and purification steps are not addressed in this chapter since, from our experience, these procedures are quite systematically protein dependent and request to be set up in a tailored-made fashion.

\section{Materials}

\subsection{Yeast Transformation}

1. The recombinant expression vector of your choice that you carefully selected (see Subheading 3.1).

2. Restriction enzyme PmeI and its specific buffer.

3. Sterile water.

4. Nucleic acid extraction and purification kit (e.g., NucleoSpin kit, Machery-Nagel).

5. Loading dye (e.g., 6x DNA gel loading dye, Thermo Scientific).

6. $1 \%(\mathrm{w} / \mathrm{v})$ agarose gels supplemented with $0.5 \mu \mathrm{g} / \mathrm{mL}$ ethidium bromide.

7. Additional equipment for agarose gel electrophoresis.

8. 24:24:1 (v/v/v) chloroform:phenol:isoamyl alcohol.

9. Chloroform.

10. $100 \%(\mathrm{v} / \mathrm{v})$ ethanol, ice cold.

11. 3 M Sodium acetate, $\mathrm{pH} 4.8$. 
12. $70 \%(\mathrm{v} / \mathrm{v})$ ethanol, ice cold.

13. Pichia pastoris strain SMD1163 streaked on a YPD plate.

14. YPD agar plates: $1 \%(\mathrm{w} / \mathrm{v})$ yeast extract, $2 \%(\mathrm{w} / \mathrm{v})$ peptone, $2 \%(\mathrm{w} / \mathrm{v})$ dextrose, $2 \%(\mathrm{w} / \mathrm{v})$ agar. Heat sterilize in autoclave.

15. Spectrophotometer .

16. 1 M 4-(2-Hydroxyethyl)piperazine-1-ethanesulfonic acid (HEPES), $\mathrm{pH} 8$.

17. 1 M Dithiothreitol (DTT).

18. $1 \mathrm{M}$ sorbitol, ice-cold.

19. $30^{\circ} \mathrm{C}$ Shaking incubator.

20. Electroporation instrument (e.g., Gene Pulser system, BioRad).

21. Sterile $0.2 \mathrm{~cm}$ electroporation cuvettes.

22. YNB plates (minimal medium): $1.34 \%(\mathrm{w} / \mathrm{v})$ yeast nitrogen base without amino acids, $2 \%$ $(\mathrm{w} / \mathrm{v})$ dextrose, $2 \%(\mathrm{w} / \mathrm{v})$ agar. Heat sterilize in autoclave.

23. All materials and solutions in contact with the cells must be sterile.

\subsection{Screening of Recombinant Clones}

1. YPD liquid medium and agar plates: $1 \%(\mathrm{w} / \mathrm{v})$ yeast extract, $2 \%(\mathrm{w} / \mathrm{v})$ peptone, $2 \%(\mathrm{w} / \mathrm{v})$ dextrose. For YPD agar plates, add $2 \%(\mathrm{w} / \mathrm{v})$ agar. Heat sterilize in autoclave. When needed, supplement with appropriate concentrations of antibiotic (typically $50-250 \mu \mathrm{g} / \mathrm{mL}$ geneticin).

2. Spectrophotometer.

3. $100 \%(\mathrm{v} / \mathrm{v})$ glycerol, autoclave sterilized.

4. 96-Well plate.

5. Sterile toothpicks or inoculating loop.

6. $30{ }^{\circ} \mathrm{C}$ Shaking incubator.

7. YEP agar medium (to be dissolved in $700 \mathrm{~mL}$ ): $10 \mathrm{~g}$ Yeast extract, $20 \mathrm{~g}$ meat peptone, $20 \mathrm{~g}$ agar. Heat sterilize in autoclave.

8. $1 \mathrm{M}$ Phosphate buffer, $\mathrm{pH}$ 6: $3.1 \%(\mathrm{w} / \mathrm{v})$ dipotassium hydrogen phosphate trihydrate $\left(\mathrm{K}_{2} \mathrm{HPO}_{4}, 3 \mathrm{H}_{2} \mathrm{O}\right), 11.81 \%(\mathrm{w} / \mathrm{v})$ potassium dihydrogen phosphate $\left(\mathrm{KH}_{2} \mathrm{PO}_{4}\right)$. Filter 
sterilize.

9. BMGY agar medium: $700 \mathrm{~mL}$ YEP agar medium (still liquid and warm), $100 \mathrm{~mL} 13.4 \%$ (w/v) yeast nitrogen base without amino acid (10× solution, filter sterilized), $100 \mathrm{~mL} 10 \%$ (v/v) glycerol (10Xx solution, filter sterilized), $100 \mathrm{~mL} 1 \mathrm{M}$ phosphate buffer, $\mathrm{pH} 6$ (10× solution, filter sterilized).

10. BMMY agar medium: $700 \mathrm{~mL}$ YEP agar medium (still liquid and warm), $100 \mathrm{~mL} 13.4 \%$ (w/v) yeast nitrogen base without amino acid (10× solution, filter sterilized), $100 \mathrm{~mL} 5 \%$ (v/v) methanol (10× solution, filter sterilized), $100 \mathrm{~mL} 1 \mathrm{M}$ phosphate buffer, $\mathrm{pH} 6$ (10x solution, filter sterilized).

11. $14 \mathrm{~cm}$ diameter Petri dishes.

12. $0.45 \mu \mathrm{m}$ Nitrocellulose blotting membrane of a 96-well plate dimension.

13. Lysis buffer: $100 \mathrm{mM}$ Tris-HCl $\mathrm{pH} 7.4,150 \mathrm{mM} \beta$-mercaptoethanol, $20 \mathrm{mM}$ ethylenediaminetetraacetic acid (EDTA), $2 \%(\mathrm{v} / \mathrm{v}) \mathrm{SDS}$, and $9 \mathrm{M}$ urea. Dissolve the components at $65^{\circ} \mathrm{C}$.

14. Whatman paper of a 96-well plate dimension.

15. $65^{\circ} \mathrm{C}$ Incubator.

\subsection{Yeast Culturing}

1. Recombinant clones freshly streaked on a YPD plate supplemented with appropriate concentrations of antibiotic (typically $50 \mu \mathrm{g} / \mathrm{mL}$ geneticin)

2. YEP medium (to be dissolved in $700 \mathrm{~mL}$ ): $10 \mathrm{~g}$ Yeast extract, $20 \mathrm{~g}$ meat peptone. Heat sterilize in autoclave.

3. 1 M Phosphate buffer, $\mathrm{pH} 6$.

4. BMGY liquid medium: $700 \mathrm{~mL}$ YEP medium, $100 \mathrm{~mL} 13.4 \%(\mathrm{w} / \mathrm{v})$ yeast nitrogen base without amino acid (10× solution, filter sterilized), $100 \mathrm{~mL} 10 \%$ (v/v) glycerol (10× solution, filter sterilized), $100 \mathrm{~mL} 1 \mathrm{M}$ phosphate buffer $\mathrm{pH} 6$ (10× solution, filter sterilized).

5. BMMY liquid medium: $700 \mathrm{~mL}$ YEP medium, $100 \mathrm{~mL} 13.4 \%$ (w/v) yeast nitrogen base without amino acid (10x solution, filter sterilized), $100 \mathrm{~mL} 5 \%(\mathrm{v} / \mathrm{v})$ methanol $(10 \times$ solution, filter sterilized), $100 \mathrm{~mL} 1 \mathrm{M}$ phosphate buffer $\mathrm{pH} 6$ (10× solution, filter sterilized).

6. Phosphate-buffered saline (PBS): $137 \mathrm{mM} \mathrm{NaCl}, 2.7 \mathrm{mM} \mathrm{KCl}, 10 \mathrm{mM} \mathrm{Na}{ }_{2} \mathrm{HPO}_{4}, 1.76 \mathrm{mM}$ $\mathrm{KH}_{2} \mathrm{PO}_{4}, \mathrm{pH} 7-7.4$.

7. Baffled flasks: $250 \mathrm{~mL}$ (small-scale culturing), 1 and $2 \mathrm{~L}$ (upscale). 
8. $30{ }^{\circ} \mathrm{C}$ Shaking incubator.

9. Spectrophotometer.

\subsection{Yeast Cell Lysis and Membrane Preparation}

1. Yeast cell pellet.

2. TNG buffer: $50 \mathrm{mM}$ Tris- $\mathrm{HCl} \mathrm{pH} 7.4,0.5 \mathrm{M} \mathrm{NaCl}, 10 \%$ (v/v) glycerol, $1 \mathrm{mM}$ PMSF (added extemporaneously).

3. TNGE buffer: $50 \mathrm{mM}$ Tris- $\mathrm{HCl} \mathrm{pH} 7.4,0.5 \mathrm{M} \mathrm{NaCl}, 10 \%$ (v/v) glycerol, $1 \mathrm{mM}$ PMSF (added extemporaneously), 1 mM EDTA.

4. Acid-washed glass beads (425 to $600 \mu$ m diameter, Sigma-Aldrich).

5. High-speed benchtop homogenizer (e.g., FastPrep 24, MP Biomedicals).

6. Ultracentrifuge equipped with an appropriate fixed-angle rotor and adapted polycarbonate bottles.

7. Potter homogenizer.

8. Protein assay kit for the determination of protein concentration (e.g., Pierce BCA Protein Assay Kit, Thermo Scientific).

\subsection{Immuno-detection}

1. $40 \%$ Acrylamide/Bis-acrylamide solution, 19:1.

2. $3 \mathrm{M}$ Tris $-\mathrm{HCl} \mathrm{pH} 8.45,0.3 \%(\mathrm{w} / \mathrm{v})$ SDS.

3. $80 \%(\mathrm{v} / \mathrm{v})$ glycerol.

4. $10 \%(w / v)$ ammonium persulfate (APS).

5. Tetramethylethylenediamine (TEMED).

6. Gel-casting stand and electrophoresis chamber (e.g., Mini-PROTEAN system, Bio-Rad).

7. Membrane preparation samples.

8. Tris-tricine-SDS cathode running buffer: $1 \mathrm{M}$ Tris- $\mathrm{HCl} \mathrm{pH} 8.2,1 \mathrm{M}$ tricine, $1 \%$ (w/v) SDS.

9. Tris anode running buffer: $1 \mathrm{M}$ Tris- $\mathrm{HCl} \mathrm{pH} 8.9$.

10. $2 \times$ Tricine sample buffer (SB 2x): $100 \mathrm{mM}$ Tris- $\mathrm{HCl} \mathrm{pH} 6.8,25 \%$ (v/v) glycerol, $8 \%$ 
(w/v) SDS, $0.02 \%(w / v)$ Coomassie blue G250, 200 mM DTT.

11. Tris-glycine transfer buffer: $25 \mathrm{mM}$ Tris base, $200 \mathrm{mM}$ glycine, $0.02 \%$ (w/v) SDS, $20 \%$ $(\mathrm{v} / \mathrm{v})$ ethanol.

12. $0.45 \mu \mathrm{m}$ Nitrocellulose blotting membrane.

13. Whatman paper.

14. Electroblotting system (e.g., Mini Trans-Blot Cell, Bio-Rad).

15. Phosphate-buffered saline (PBS).

16. PBS containing $0.02 \%(\mathrm{v} / \mathrm{v})$ Tween $80(\mathrm{PBST})$.

17. Blocking buffer: PBST with $5 \%$ (w/v) nonfat dry milk.

18. Primary anti-tag or anti-protein antibody (e.g., monoclonal anti-FLAG antibody from mouse, Sigma).

19. Secondary anti-mouse $\operatorname{IgG}$ antibody linked to a reporter system (traditionally HRP-conjugated antibody, here an IRD800-coupled antibody).

20. Reagents and detection device adapted to the reporter system selected.

21. Orbital shaker.

22. Microfiltration blotting device (e.g., Bio-Dot apparatus, Bio-Rad).

\subsection{Radioligand Binding Assay}

1. Membrane preparation samples.

2. EMP-specific binding buffer (here: $50 \mathrm{mM}$ Tris- $\mathrm{HCl} \mathrm{pH} 7.4,5 \mathrm{mM} \mathrm{MgCl} 2,1 \mathrm{mM}$ EDTA).

3. Filter preincubation buffer: $50 \mathrm{mM}$ Tris- $\mathrm{HCl} \mathrm{pH} \mathrm{7.4,0.3 \% (v/v)} \mathrm{polyethylenimine}$ . Please insert the composition of the washing buffer below

4. Washing buffer : $50 \mathrm{mM}$ Tris- $\mathrm{HCl} \mathrm{pH}$ 7.4.

4. Nonradioactive, EMP-specific ligand, here melatonin.

5. Radiolabeled ligand, here $\left[{ }^{3} \mathrm{H}\right]$-O-methyl-melatonin (Perkin Elmer).

6. Scintillation cocktail (e.g., Microscint-O scintillation fluid, Perkin Elmer).

7. Low-protein-binding 96-well plate.

8. Shaking incubator. 
9. GF/B-grade glass-fiber Unifilters (Perkin Elmer).

10. Scintillation counter.

11. Manifold vacuum filtration apparatus, here a Unifilter-96 harvester (Perkin Elmer).

12. Analysis software (e.g., Prism4, GraphPad Software).

\section{Methods}

\subsection{P. pastoris Vector Design and Cloning Procedure}

P. pastoris expression vectors are built on a classical E. coli/yeast shuttle model with components required for $E$. coli amplification (classically one origin of replication and one antibiotic selection marker) and specific elements for heterologous gene expression in P. pastoris. These typically include a selectable auxotrophy marker and/or an antibiotic resistance bacterial gene, as well as a promoter and a terminator sequences surrounding a cloning cassette.

The $P$. pastoris system offers a wide range of plasmid backbones, selection markers, promoters, and fusion sequences that can be combined to obtain the best-suited vector for a given protein. For an exhaustive description of the different elements available and guidelines to choose their assembly, we recommend the reader a chapter from a previous volume of the Methods in Molecular Biology series [11] that is fully dedicated to these aspects.

The examples illustrating the methods presented here are based on the utilization of modified pPIC9K vectors (Life Technologies) designed for the large-scale production of EMPs as described in [7] and [10] notably. Briefly, this vector comprises the gene coding for histidinol dehydrogenase (HIS4) as an auxotrophy marker, as well as a bacterial gene (Kan) conferring P. pastoris resistance to geneticin. The gene coding for the protein of interest is expressed under the control of the strong $\mathrm{P}_{\text {AOXI }}$ promoter, which is induced by methanol in the absence of other preferential carbohydrate source. The recombinant proteins are flanked at their N- and/or C-termini by a panel of tags (Flag, decahistidine, c-myc, biotinylation domain), which are used for analysis and/or purification purposes. If the fusion sequences need to be eliminated during or after the purification process, tobacco etch virus (TEV) protease sites may be inserted on both sides of the protein to be expressed.

\subsection{Preparation of the Expression Vector}

Contrary to other yeast systems, no autonomously replicating vectors are available for P. pastoris, so they are designed to be integrated in the yeast genome. This is achieved by homologous recombination events that naturally occur between linearized sequences carried by the plasmids (typically HIS4 or $\mathrm{P}_{A O X I}$ ) and their homologous counterparts present on the genome, leading to the targeted insertion of the expression vectors. Moreover, such plasmid insertions frequently occur in tandem in yeasts and thus lead to multiple integration of the gene of interest with an associated impact on its expression levels.

We describe here a transformation protocol based on the electroporation of the P.pastoris SMD1163 strain (his4, pep4, prbl) (see Note 1-).

1. Digest 5-7 $\mu \mathrm{g}$ of the purified expression vector with PmeI restriction enzyme (see Note 2-) 
according to the manufacturer's instructions (typically mix 5-7 $\mu \mathrm{g}$ of the expression vector with $25 \mathrm{U}$ of PmeI, $20 \mu \mathrm{L}$ of $10 \times$ corresponding buffer, and sterile water to a final volume of $200 \mu \mathrm{L}$; incubate the reaction for $2 \mathrm{~h}$ at $37^{\circ} \mathrm{C}$ ).

2. Purify the DNA using the NucleoSpin kit. Alternatively to the use of a commercial kit for the purification of restriction-digested plasmids, we routinely perform this phenolchloroform extraction procedure that yields a high-quality DNA leading to optimal transformation efficiencies (see protocol detailed in steps 3-10).

3. Add $400 \mu \mathrm{L}$ of $24: 24: 1$ (v/v/v) chloroform:phenol:isoamyl alcohol to $200 \mu \mathrm{L}$ of digestion mixture.

4. Centrifuge for $5 \mathrm{~min}$ at $18,000 \times g$, room temperature, and transfer the upper aqueous phase to a new $1.5 \mathrm{~mL}$ microcentrifuge tube.

5. Add $400 \mu \mathrm{L}$ of chloroform and vortex thoroughly for about $20 \mathrm{~s}$.

6. Centrifuge for $5 \mathrm{~min}$ at $18,000 \times g$, room temperature, and transfer the upper aqueous phase to a new $1.5 \mathrm{~mL}$ microcentrifuge tube.

7. Add $1 \mathrm{~mL}$ of $100 \%$ ethanol and $50 \mu \mathrm{L}$ of $3 \mathrm{M}$ sodium acetate and incubate for at least $1 \mathrm{~h}$ at $-20{ }^{\circ} \mathrm{C}$ to precipitate the DNA.

8. Centrifuge for $30 \mathrm{~min} 18,000 \times g, 4^{\circ} \mathrm{C}$. Discard the supernatant.

9. Wash the pellet with $100 \mu \mathrm{L}$ of $70 \%(\mathrm{v} / \mathrm{v})$ ethanol and centrifuge for $5 \mathrm{~min}$ at $18,000 \times g, 4$ ${ }^{\circ} \mathrm{C}$. Discard the supernatant.

10. Air-dry the pellet for $15 \mathrm{~min}$ and then resuspend in $15 \mu \mathrm{L}$ sterile $\mathrm{H}_{2} \mathrm{O}$.

11. Check the DNA linearization by loading $1 \mu \mathrm{L}$ of the reaction mix on a $1 \%(\mathrm{w} / \mathrm{v})$ agarose gel (see Note 3-).

\subsection{Preparation of P. pastoris Electrocompetent Cells (See Note 4-)}

1. To prepare about $500 \mu \mathrm{L}$ of electrocompetent $P$. pastoris cells, inoculate $100 \mathrm{~mL}$ YPD medium with a fresh SMD1163 colony and incubate overnight at $30{ }^{\circ} \mathrm{C}$ in a shaking incubator.

2. Measure the $\mathrm{OD}_{600}$ of the culture with a spectrophotometer, dilute the culture with $400 \mathrm{~mL}$ fresh YPD to obtain an $\mathrm{OD}_{600}$ of 0.25 , and incubate at $30{ }^{\circ} \mathrm{C}$ (see Note 5-).

3. When the culture reaches an $\mathrm{OD}_{600}$ of 1 (approximately after $4 \mathrm{~h}$ ), harvest the cells by centrifugation in sterile tubes for $5 \mathrm{~min}$ at $4000 \times \mathrm{g}, 4^{\circ} \mathrm{C}$.

4. Discard the supernatant and resuspend the cells in $100 \mathrm{~mL}$ YPD, $20 \mathrm{~mL}$ of $1 \mathrm{M}$ HEPES pH 8 , and $2.5 \mathrm{~mL}$ of $1 \mathrm{M} \mathrm{DTT}$. Mix gently until the pellet is resuspended. 
5. Incubate for $15 \mathrm{~min}$ at $30^{\circ} \mathrm{C}$.

6. Transfer onto ice and add ice-cold sterile $\mathrm{H}_{2} \mathrm{O}$ to a final volume of $500 \mathrm{~mL}$.

7. Pellet the cells by centrifuging for $5 \mathrm{~min}$ at $4000 \times g, 4{ }^{\circ} \mathrm{C}$.

8. Discard the supernatant and wash the cell pellet with $250 \mathrm{~mL}$ ice-cold sterile $\mathrm{H}_{2} \mathrm{O}$.

9. Pellet the cells by centrifuging for $5 \mathrm{~min}$ at $4000 \times g, 4{ }^{\circ} \mathrm{C}$.

10. Discard the supernatant and resuspend the cell pellet in $20 \mathrm{~mL}$ ice-cold $1 \mathrm{M}$ sorbitol by gently mixing.

11. Pellet the cells by centrifuging for $5 \mathrm{~min}$ at $4000 \times g, 4{ }^{\circ} \mathrm{C}$.

12. Discard the supernatant and resuspend the cell pellet in $500 \mu \mathrm{L}$ ice-cold $1 \mathrm{M}$ sorbitol by gently mixing.

\subsection{Electro-transformation and Selection of the Recombinant Clones}

1. Place an electroporation cuvette on ice at least 10-15 min before performing the transformation.

2. Mix gently $40 \mu \mathrm{L}$ competent cells with $7.5 \mu \mathrm{L}$ of the linearized DNA in the cuvette and incubate for $5 \mathrm{~min}$ on ice.

3. Adjust the electroporation settings as follows: $1500 \mathrm{~V}, 25 \mu \mathrm{F}$, and $400 \Omega$.

4. Place the cuvette in the electroporator chamber and apply the electric pulse.

5. Immediately resuspend the electroporated mixture in $1 \mathrm{~mL}$ ice-cold $1 \mathrm{M}$ sorbitol and transfer into a sterile tube.

6. Allow the cells to recover for about $1 \mathrm{~h}$ at $30^{\circ} \mathrm{C}$, and then pellet the cells by centrifuging for $10 \mathrm{~min}$ at $4000 \times g$, room temperature.

7. Discard the supernatant and resuspend the pellet in $500 \mu \mathrm{L}$ of $1 \mathrm{M}$ sorbitol.

8. Spread, respectively, $10 \%(50 \mu \mathrm{L})$ and $90 \%(450 \mu \mathrm{L})$ of electrotransformed cells on each of the two YNB plates and incubate for $2-3$ days at $30{ }^{\circ} \mathrm{C}$ (see Note 6-).

\subsection{Screening of Recombinant Clones}

When using expression vectors comprising the HIS4 auxotrophy selection marker (e.g., vectors from the pPIC9K series), recombinant yeast clones are selected in two consecutive steps. The first one, performed after the electrotransformation, is based on the recovery of histidine prototrophy through growth ability on minimal medium. The second one is dedicated to the identification of multicopy transformants producing high yields of recombinant proteins. Indeed, a high number of integrated 
copies often (but not always) correlates with higher expression levels, and it is necessary to screen several His + transformants in order to identify a high producer.

To this end, we propose two different procedures: either a classical one in which His + transformants are selected on YPD plates containing a range of geneticin concentrations or a more high-throughput immunostaining method named Yeastern blot in which histidine-prototroph clones are grown in expression conditions and lysed directly on a nitrocellulose membranes in a 96-well plate format.

The goal of the-screening on increasing geneticin concentration is to select clones with geneticin resistance phenotypes representative of the number of expression vector-integrated copies (the higher number of integrated copies, the potentially higher resistance level), before evaluating their performance in terms of EMP expression (see Note 7-).

1. Harvest the His + transformants with $1 \mathrm{~mL}$ of YPD medium poured onto the YNB plates and scrape off all the clones using a sterile scraper.

2. Perform $10 \times$ and $100 \times$ dilutions and measure the $\mathrm{OD}_{600}$ for each.

3. Spread an equivalent of $10^{5}$ cells/plate $\left(\mathrm{OD}_{600}\right.$ of 1 is equivalent to approximately $5 \times 10^{7}$ cells $/ \mathrm{mL}$ ) on YPD plates supplemented with increasing geneticin concentrations ranging from 50 to $250 \mu \mathrm{g} / \mathrm{mL}$ (see Notes 8 and 9).

4. Incubate for $2-3$ days at $30^{\circ} \mathrm{C}$.

5. Pick 6-12 representative colonies from the different geneticin concentration plates, streak them onto a fresh YPD plate supplemented with $50 \mu \mathrm{g} / \mathrm{mL}$ geneticin, and let them grow for $1-2$ days at $30{ }^{\circ} \mathrm{C}$.

6. Directly use these colonies for further expression tests and/or resuspend them in $1 \mathrm{ml}$ of sterile YPD supplemented with $20 \%$ glycerol and store them at $-80{ }^{\circ} \mathrm{C}$.

The goal of the high-throughput expression-level screening assay or yeastern blotting that we developed is to screen at once the largest number of EMP-expressing clones with the fewest and simplest handling steps. Therefore, no selection based on geneticin resistance phenotypes is required (see Note 10-).

Steps 1-8 must be performed in sterile conditions.

1. Fill each well of a 96-well plates with $100 \mu \mathrm{L}$ YPD supplemented with $20 \mu \mathrm{g} / \mathrm{mL}$ geneticin.

2. Inoculate each well with a single His + colony (from the YNB plate) with a sterile toothpick or inoculation loop.

3. Incubate overnight on a shaker at $250 \mathrm{rpm}, 30{ }^{\circ} \mathrm{C}$.

4. On the next day, place a sterile nitrocellulose membrane on a BMGY plate (14 cm diameter) avoiding air bubbles.

5. With a multichannel pipette, spot $5 \mu \mathrm{L}$ of each preculture on the membrane. Add $20 \mu \mathrm{L}$ sterile glycerol in each well and conserve the plate at -20 or $-80{ }^{\circ} \mathrm{C}$. 
6. Incubate for about $12 \mathrm{~h}$ at $30^{\circ} \mathrm{C}$ (plate lid on the top).

7. After incubation, transfer the membrane on a BMMY plate avoiding air bubbles.

8. Incubate for about $20 \mathrm{~h}$ at $30{ }^{\circ} \mathrm{C}$ (plate lid on the top).

9. In a petri dish, soak 12 Whatman paper sheets in lysis buffer. The liquid level should not recover the last sheet.

10. Transfer the nitrocellulose membrane on top of the Whatman paper pile avoiding air bubbles.

11. Incubate for $4 \mathrm{~h}$ at $65^{\circ} \mathrm{C}$.

12. After lysis, rinse generously the membrane with water to get rid of all visible yeast cell traces and proceed to standard immunodetection of the protein of interest as described in Subheading 3.8. Figure 1 presents two examples of GPCR-expressing colonies assayed witl this method that are representative of the typical patterns that can be obtained. This immunoblot clearly highlights clones that exhibit high expression levels of the proteins of interest.

\section{Fig. 1}

Yeastern blot analysis of ca. 96 recombinant $P$. pastoris clones expressing class A GPCRs (a) Flag-tagged human B2AR receptor; (b) flag-tagged human NPFFR2 receptor. Ctrl colony expressing the AA2A receptor used as a positive control. After expression inductio and direct lysis of the colonies grown on the nitrocellulose membrane, the tagged receptor were immunodetected with an M2 anti-flag antibody 
a B2AR

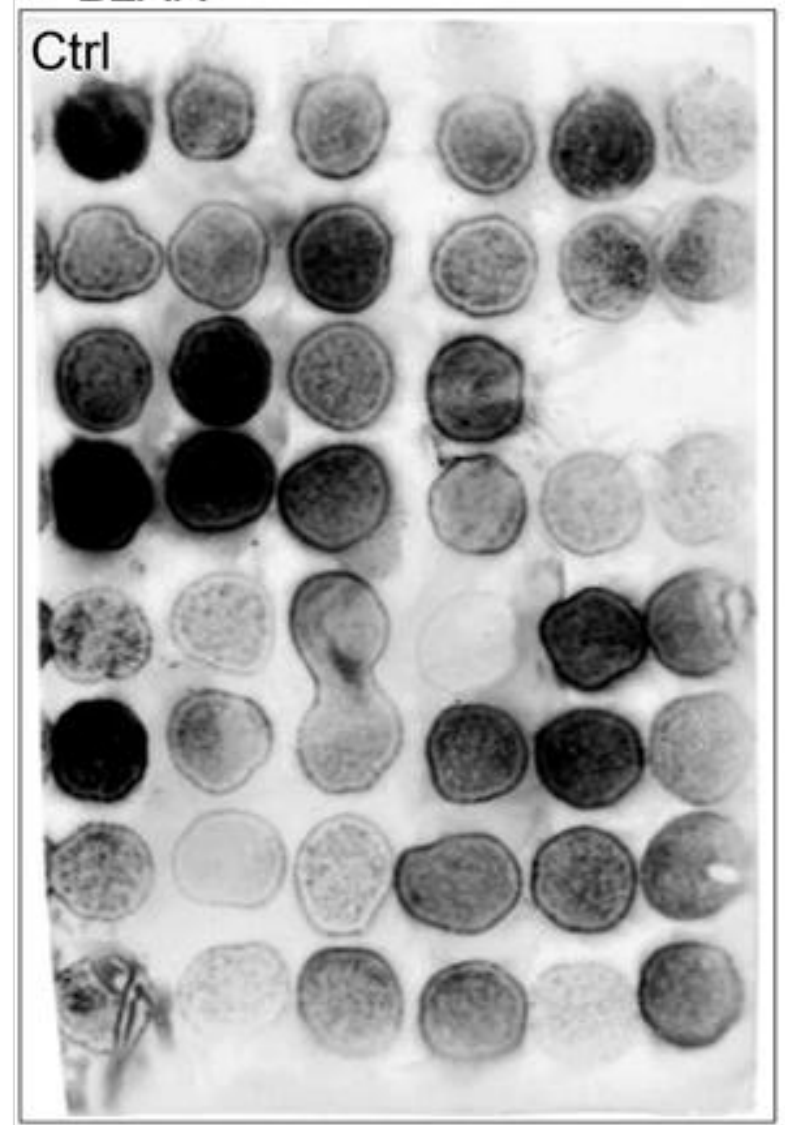

b NPFFR2

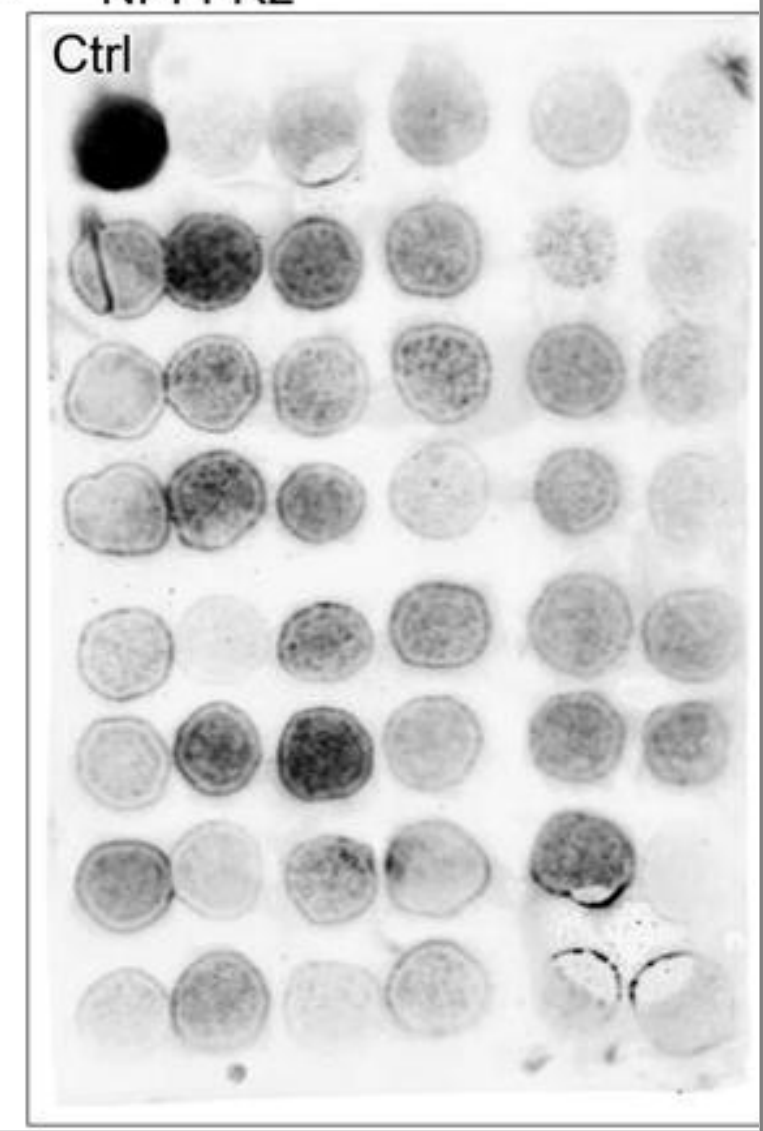

13. Streak the high-expressing clones onto a fresh YPD plate supplemented with $50 \mu \mathrm{g} / \mathrm{mL}$ geneticin and let them grow for $1-2$ days at $30^{\circ} \mathrm{C}$.

14. Directly use these colonies for further expression tests and/or resuspend them in $1 \mathrm{ml}$ of sterile YPD supplemented with $20 \%$ glycerol and store them at $-80{ }^{\circ} \mathrm{C}$.

\subsection{Yeast Culturing for Membrane Protein Expression}

Once interesting transformants have been identified, their expression abilities should be further explored in liquid culture. For expression based on $\mathrm{P}_{A O X 1}$-dependent vectors, yeasts are first cultured in a glycerol-containing medium to an appropriate cell density and growth phase.

Transferring the cells into a methanol-containing medium then induces protein expression.

The procedure presented below describes small-scale culturing using shaken baffled flasks, which allows the parallel screening of several clones. It can easily be up-scaled to bigger baffled flasks for the production of larger amounts of EMP (see Note 11-).

1. Inoculate $50 \mathrm{~mL}$ of freshly prepared BMGY medium in a $250 \mathrm{~mL}$ baffled flask with a fresh recombinant colony isolated on a YPD agar plate. Incubate on a shaker at $250 \mathrm{rpm}, 30^{\circ} \mathrm{C}$, $\mathrm{ON}$.

2. On the next day, measure the $\mathrm{OD}_{600}$ of the culture. Dilute the cells into $50 \mathrm{~mL}$ of fresh BMGY medium in a $250 \mathrm{~mL}$ flask to achieve an $\mathrm{OD}_{600}$ of 1 (about $5 \times 10^{7}$ cells $/ \mathrm{mL}$ ) and incubate on a shaker at $250 \mathrm{rpm}, 30^{\circ} \mathrm{C}$. This step usually corresponds to a tenfold dilution of the pre-culture. 
3. When the culture reaches $\approx 5 \mathrm{OD}_{600}$ (about $5 \mathrm{~h}$ later), pellet the cells by centrifuging in sterile tubes for $5 \mathrm{~min}$ at $4000 \times g$, room temperature.

4. Discard the supernatant and resuspend the cell pellet with $50 \mathrm{~mL}$ fresh BMMY medium (see Note 12 ). Incubate for $18-24 \mathrm{~h}$ in a shaker at $30{ }^{\circ} \mathrm{C}, 250 \mathrm{rpm}$.

5. After induction, harvest the cells by centrifuging for $5 \mathrm{~min}$ at $4000 \times g, 4{ }^{\circ} \mathrm{C}$.

6. Discard the supernatant and wash the cell pellet with $50 \mathrm{~mL}$ PBS. Pellet the cells by centrifuging for $5 \mathrm{~min}$ at $4000 \times g, 4^{\circ} \mathrm{C}$.

7. Discard the supernatant and weigh the cell pellet. At this stage, the cell pellet can either be snap-frozen in liquid nitrogen and stored at $-80{ }^{\circ} \mathrm{C}$, or kept on ice to be directly used for membrane preparation.

\subsection{Yeast Cell Lysis and Membrane Preparation Procedure}

P. pastoris cells are surrounded by a thick protective cell wall, resulting in the need to use a robust cell lysis method. The protocol described below involves glass microbeads associated with vigorous mechanical shaking. Programmable equipment such as the FastPrep 24 from MP Biomedicals employed here can be used to achieve reliable and reproducible results. It can also be adapted to various sample volumes and formats (from $1.5 \mathrm{~mL}$ microcentrifuge tubes to $50 \mathrm{~mL}$ conical centrifuge tubes). However, similar results can be obtained using a basic vortex apparatus in 4-8 cycles of alternating shaking and ice-cooling phases.

1. Resuspend the yeast pellet obtained (about $1 \mathrm{~g}$ wet cells) with $10 \mathrm{~mL}$ ice-cold TNGE buffer in a $50 \mathrm{~mL}$ conical centrifuge tube.

2. Add $5 \mathrm{~mL}$ of acid-washed glass beads.

3. Place the tubes on the cell breaker device and proceed to cell lysis by alternating shaking and cooling steps on ice (3 cycles of $40 \mathrm{~s}$ each at $6.5 \mathrm{~m} / \mathrm{s}$ on a FastPrep 24).

4. Centrifuge the samples for $5 \mathrm{~min}$ at $4000 \times g, 4{ }^{\circ} \mathrm{C}$, collect the supernatant, and store at $4{ }^{\circ} \mathrm{C}$.

5. Dissolve the remaining pellet in $10 \mathrm{~mL}$ ice-cold TNGE buffer.

6. Repeat steps 3-4 times (or until the supernatant is clear).

7. Centrifuge the collected supernatants for an additional $5 \mathrm{~min}$ at $4000 \times g, 4{ }^{\circ} \mathrm{C}$.

8. Proceed to supernatant ultracentrifugation for $30 \mathrm{~min}$ at $100,000 \times g, 4{ }^{\circ} \mathrm{C}$.

9. Discard the supernatant and resuspend the membrane pellet with a Potter homogenizer in 3 $\mathrm{mL}$ ice-cold TNG buffer until a homogeneous suspension is obtained.

10. Determine the protein concentration using the BCA assay kit following the manufacturer's recommendations. 
11. Use directly the membrane preparation for expression-level analysis or purification, or store them at $-80{ }^{\circ} \mathrm{C}$.

\subsection{Membrane Analysis Procedure: Immunodetection}

Immunodetection methods allow the determination of the overall amount of the recombinant EMP contained in the membrane preparations. These analyses can be performed using specific antibodies targeted against the EMP of interest or against the tags fused to the protein.

The expression level can either be estimated on membrane samples previously separated by a denaturing SDS-PAGE or directly by spotting membrane preparation on a nitrocellulose membrane with a dot-blot device. Both methods are presented below.

The following proportions are given for casting two gels of $1 \mathrm{~mm}$ thickness in a standard Mini-Protean system from Bio-Rad.

1. Prepare the separating gel by mixing $2.5 \mathrm{~mL}$ of the acrylamide solution, $3.3 \mathrm{~mL}$ Tris- $\mathrm{HCl}$ SDS buffer, $1.25 \mathrm{~mL} 80 \%$ (v/v) glycerol, and $2.9 \mathrm{~mL} \mathrm{H}_{2} \mathrm{O}$. Add $90 \mu \mathrm{L}$ APS and $6 \mu \mathrm{L}$ TEMED, mix, and immediately cast the gel. Allow space to cast the stacking gel.

2. Prepare the stacking gel by mixing $0.6 \mathrm{~mL}$ of the acrylamide solution, $1.6 \mathrm{~mL}$ Tris- $\mathrm{HCl}$ SDS buffer, and $4.1 \mathrm{~mL} \mathrm{H}_{2} \mathrm{O}$. Add $90 \mu \mathrm{L}$ APS and $6 \mu \mathrm{L}$ TEMED, mix, and cast carefully over the separating gel. The presence of glycerol in the separating part avoids the need to wait for its complete polymerization. Insert a 10 -well gel comb immediately without introducing air bubbles.

3. Let polymerize for about $30 \mathrm{~min}$.

4. Preincubate $10 \mu \mathrm{g}$ of membrane preparation in SB $2 \times$ for about $10 \mathrm{~min}$ at room temperature (see Note 13-).

5. Load the sample in a well of a $10 \%$ SDS-polyacrylamide gel. Proceed to electrophoresis using Tris-tricine-SDS cathode running buffer and Tris anode running buffer in a tank unit for about $1 \mathrm{~h} 30 \mathrm{~min}$ at $100 \mathrm{~V}$.

6. Transfer the proteins from the gel to a nitrocellulose membrane by electroblotting in Tris-glycine transfer buffer for about $1 \mathrm{~h} 30 \mathrm{~min}$ at $100 \mathrm{~V}$.

7. Incubate the membrane in $50 \mathrm{~mL}$ blocking buffer for $1 \mathrm{~h}$ at room temperature on an orbital shaker. Alternatively, incubate the membrane overnight at $4{ }^{\circ} \mathrm{C}$.

8. Remove the blocking solution and incubate the membrane with the selected antibody diluted in blocking buffer (for instance a monoclonal anti-flag antibody at a final concentration of $0.1 \mu \mathrm{g} / \mathrm{mL}$ ) for $1 \mathrm{~h}$ at room temperature on an orbital shaker.

9. Wash the membrane three times, each time with $50 \mathrm{~mL}$ PBST on an orbital shaker for $5 \mathrm{~min}$ at room temperature.

10. Remove the PBST and incubate the membrane with the adapted anti-IgG antibody diluted 
in blocking buffer (typical final concentration of $0.1 \mu \mathrm{g} / \mathrm{mL}$ ) for $1 \mathrm{~h}$ at room temperature on an orbital shaker.

11. Wash the membrane three times, each time with $50 \mathrm{~mL}$ PBST on an orbital shaker for 5 min at room temperature.

12. Remove the PBST and wash the membrane with $50 \mathrm{~mL}$ PBS on an orbital shaker for $5 \mathrm{~min}$ at room temperature.

13. Store the membrane in PBS until revelation.

14. Proceed to membrane revelation according to the reporter system selected and following the manufacturer's recommendations. Figure 2 exemplifies a typical Western blot profile obtained for membrane samples prepared from different clones expressing the same EMP construct (here a 1 TM human enzyme). This example illustrates the variation of expression levels that can be observed between clones, from no (clone \#7) to low (clone \#3) and relatively high (clone \#4) amounts of protein produced.

\section{Fig. 2}

Western blot analysis of membrane samples from eight different recombinant $P$. pastoris clones expressing a native 1TM, ER-located, human enzyme. Ctrl: membrane sample of a clone used as a positive control, expressing a tagged version of the ER enzyme. Equal amounts of membrane proteins were loaded in each lane $(10 \mu \mathrm{g})$. Proteins were separated by a $10 \%$ SDS-PAGE and immunoblotted with a protein-specific monoclonal antibody. Molecular weights are indicated in kilo Daltonkilodalton (kDa) on the left.

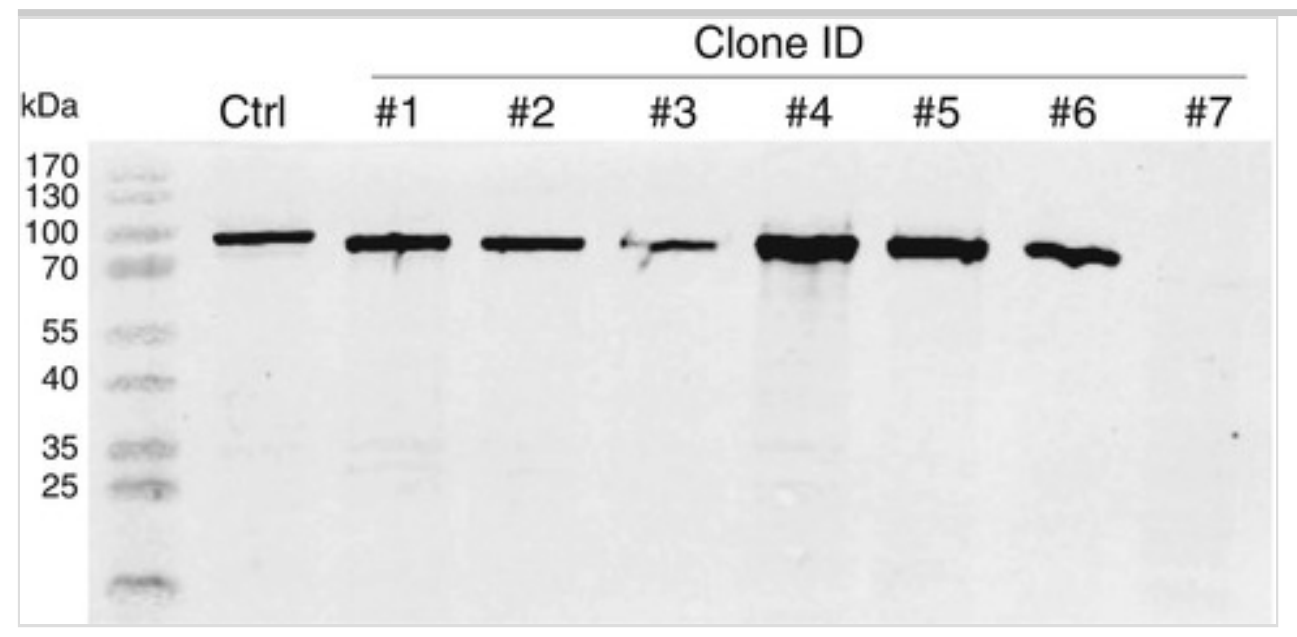

For Dot-Blot Immunodetection

1. Pre-soak with PBS a piece of nitrocellulose membrane and fix it tightly into the microfiltration-blotting device following the manufacturer's instructions.

2. Pipet $100 \mu \mathrm{L}$ of PBS into each well of the blotting device and let it flow through the nitrocellulose membrane by applying the vacuum.

3. Turn the vacuum off and pipet 5-10 $\mu \mathrm{g}$ of membrane protein samples into the 
appropriate wells. Incubate for $5 \mathrm{~min}$ at room temperature before applying the vacuum.

4. Turn the vacuum on and wash the wells three times, each time with $100 \mu \mathrm{L}$ PBS.

5. Remove the nitrocellulose membrane from the blotting device and proceed to the blocking and immunodetection reactions (as already described). Figure 3 provides an illustration of how this approach could be helpful in two different applications. With a higher throughput than a Western blot, the first application (panel A) is the ranking of several individual clones on their capacity to produce the recombinant EMP of interest. In a second direction, this method allows to screen relatively easily a number of parameters that may influence the yields of the expressed protein. The present example notably highlights the significant effect of induction time and temperature on the expression levels of a class C GPCR, but several other parameters may also be influential as shown in a number of studies (see Note 12 )).

\section{Fig. 3}

Dot blot comparisons of membrane samples from independent $P$. pastoris clones induced in different conditions for the expression of a human class C GPCR. (a) Membrane samples from 11 different clones (\#1 to \#11) induced with methanol for $18 \mathrm{~h}$ at $20^{\circ} \mathrm{C}$. (b) Membranes from clones \#1, \#8, and \#10 induced at various temperatures $\left(20,25\right.$, and $\left.30^{\circ} \mathrm{C}\right)$ and for different periods of time $(18,24,48$, and $72 \mathrm{~h}$ ). Equal amounts of corresponding membrane proteins $(10 \mu \mathrm{g})$ were loaded in each well of the blotting device and immunoblotted with an M2 anti-flag antibody $(0.1 \mu \mathrm{g} / \mathrm{mL})$

\section{AQ2}

a

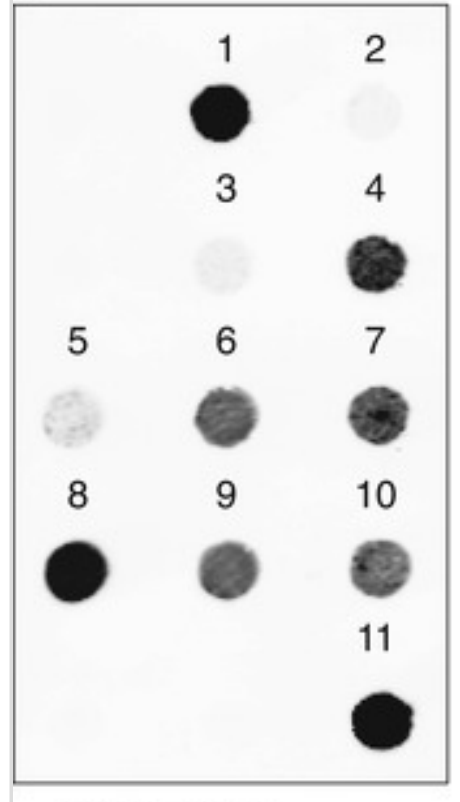

$20^{\circ} \mathrm{C}, 18 \mathrm{~h} 00$ b

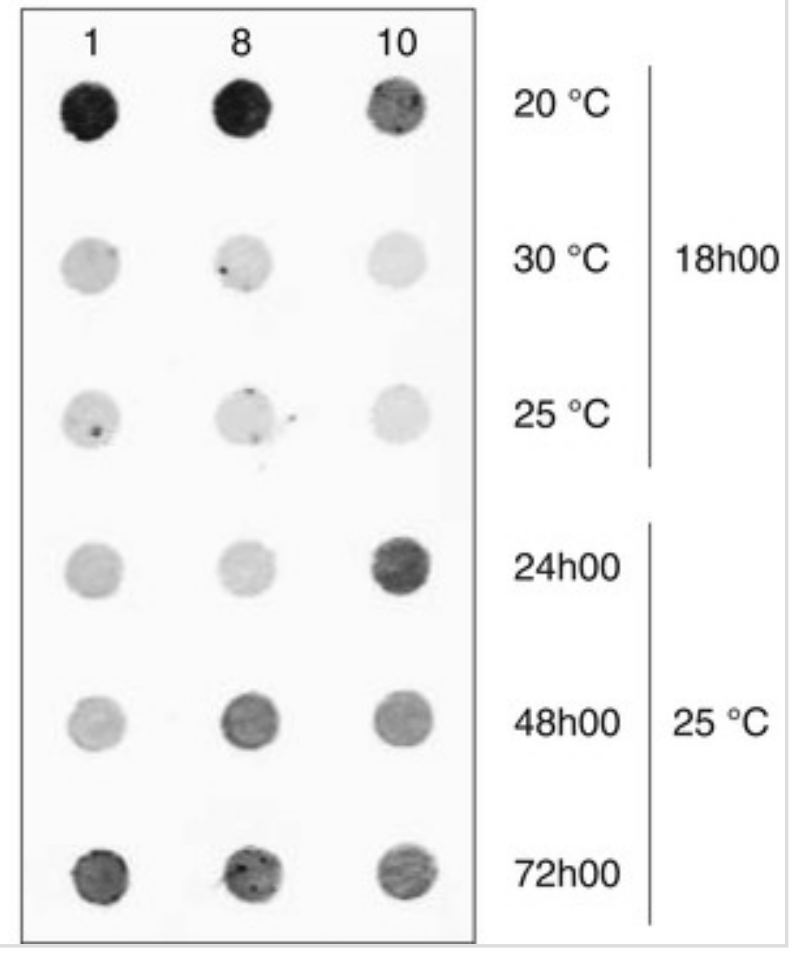




\subsection{Membrane Analysis Procedure: Radioligand Binding Assay}

In the case of GPCRs and other ligand-regulated EMPs, ligand binding assays are highly valuable procedures to infer the amounts of active receptors $\left(B_{\max }\right)$ in a membrane preparation and their affinity $\left(K_{\mathrm{d}}\right)$ for the ligand tested. These very sensitive and reliable techniques however suppose the availability of protein-specific radiolabeled ligands and an access to a lab facility where radioactive material can be handled.

In the following protocol, a saturation ligand binding procedure is exemplified with a class A GPCR, the MT1 melatonin receptor, assayed with the $\left[{ }^{3} \mathrm{H}\right]-\mathrm{O}-$ methyl-melatonin used as the tracer radioligand, and the agonist melatonin used to determine the nonspecific binding.

1. Thaw and homogenize membrane preparations on ice.

2. For each concentration of radiolabeled ligand assayed (e.g., 0.5, 1, 2, 5, 10, 20, and $50 \mathrm{nM}$ ), ligand-binding measurements are performed in triplicate for total (T) binding and in parallel for nonspecific (NS) binding (i.e., 6-point measurement for each concentration of radioligand).

3. Fill each $\mathrm{T}$ well with $10 \mu \mathrm{g}$ membrane proteins diluted in $90 \mu \mathrm{L}$ binding buffer.

4. Fill each NS well with $10 \mu \mathrm{g}$ membrane proteins diluted in $80 \mu \mathrm{L}$ binding buffer. Add $10 \mu \mathrm{L}$ of $100 \mu \mathrm{M}$ nonradioactive ligand (for a final cold ligand concentration of $10 \mu \mathrm{M}$ ).

5. Add to each well $10 \mu \mathrm{L}$ of tenfold concentrated radiolabeled ligand to achieve the concentration range of $0.5,1,2,5,10,20$, and $50 \mathrm{nM}$ in a final volume of $100 \mu \mathrm{L}$.

6. Incubate at room temperature on a shaker for $2 \mathrm{~h}$ to achieve ligand-binding equilibrium.

7. During the incubation or at least 15 min prior to filtration, pre-soak the GF/B filters in filter buffer.

8. Terminate the reactions by a rapid filtration of the samples through the pre-soaked GF/B filters using a vacuum manifold according to the manufacturer's instructions.

9. Wash the filters three times with ice-cold washing buffer.

10. Transfer the filters into scintillation vialsLet the 96 -well plate filter dry and add $3 \mathrm{~mL} 40 \mu \mathrm{L}$ scintillation cocktail.

11. Incubate the vials for $2 \mathrm{~h}$ in the dark before proceeding to counting.

12. Subtract the NS from the T values to determine specific (S) binding values. Analyze the data by nonlinear regression using appropriate software.

Figure 4 represents a typical saturation binding curve obtained with membranes of a $P$. pastoris clone expressing the MT1 receptor. In the present case, the GraphPad Prism software determined from these data a $B_{\max }$ value of $11.9 \pm 0.4 \mathrm{pmol} / \mathrm{mg}$ and a $K_{\mathrm{D}}$ of $7.2 \pm 0.8 \mathrm{nM}$. According to the conversion factors detailed in [3], the total number of ligand-binding sites $\left(B_{\max }\right)$ present in this membrane sample approximately corresponds to about $0.5 \mathrm{mg}$ of active receptor produced per 11 of 
culture. On the other side, the measured $K_{\mathrm{D}}$ value suggests that the affinity of MT1 for its agonist ligand melatonin is decreased about tenfold in $P$. pastoris membranes compared to the receptor expressed in mammalian cells [10].

\section{Fig. 4}

Radioligand binding saturation curve determined on membranes of a $P$. pastoris clone expressing the human MT1 melatonin receptor. The specific binding curve (black circles) is calculated by subtracting the nonspecific (triangles) to the total (squares) binding values. Data are fitted using the one-site saturation binding model

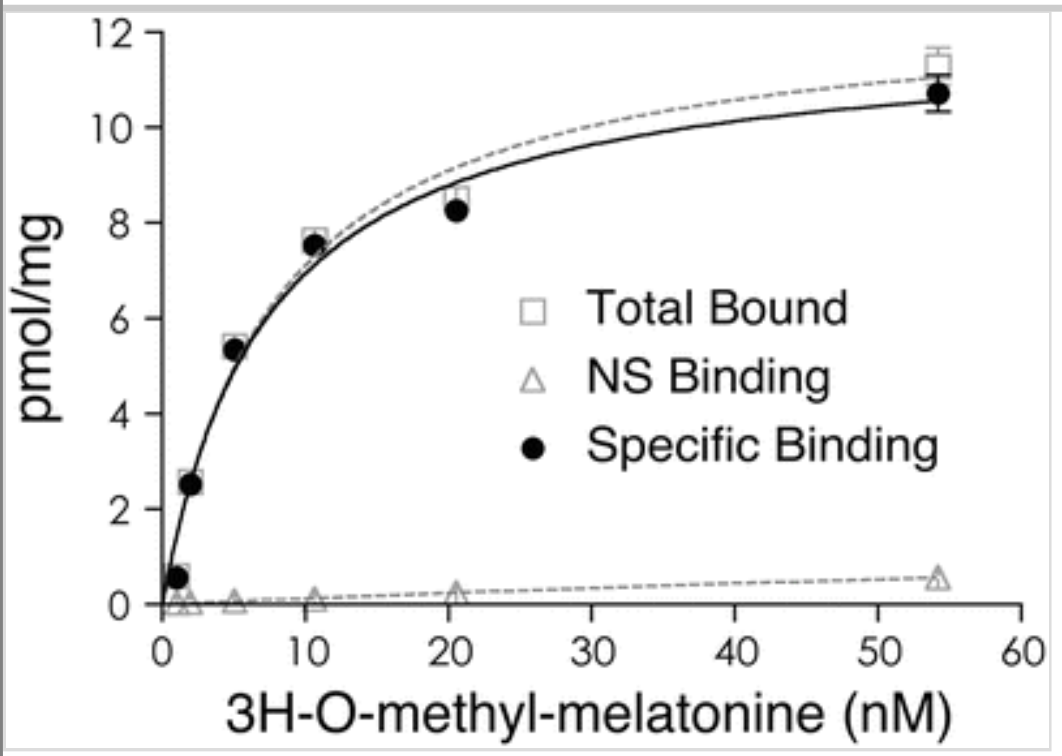

\section{Notes}

1. A number of P.pastoris strains that are frequently used for EMP expression present an auxotrophic behavior for histidine due to a histidinol dehydrogenase deficiency (his4 genotype). The prototrophy for histidine can be restored upon transformation with a series of pPIC vectors bearing the HIS4 gene, thereby allowing positive selection of the transformants on minimum medium. Strains from the SMD series bear additional deficiencies in endogenous proteases (pep4, prb1 for SMD1163) and are often preferred for this convenient phenotype (see ref. 10 for more details).

2. PmeI is used to linearize the expression vector in the $\mathrm{P}_{A O X I}$ promoter, thus favoring its integration at the homologous $\mathrm{P}_{A O X I}$ genomic locus. The absence of the PmeI site in the gene to be expressed should be checked; otherwise several fragments would be generated instead of a linearized vector. In case PmeI is present, another restriction enzyme that cut only once in the $\mathrm{P}_{A O X 1}$ or HIS4 sequences of the vector can be selected instead (SacI or SalI for instance).

3. When the plasmid is correctly linearized, one single DNA band of the corresponding size should be observed. If additional bands of nonlinearized plasmid are present, proceed back to step 1 and double the amount of PmeI restriction enzyme.

4. Unlike bacteria, yeast cells cannot conserve their competence properties when stored at -80 
${ }^{\circ} \mathrm{C}$. Electrocompetent P. pastoris cells should then be prepared extemporaneously before each transformation experiment.

5. One $\mathrm{OD}_{600}$ unit measured with an Eppendorf Biophotometer approximately corresponds to $5 \times 10^{7}$ cells $/ \mathrm{mL}$. In order to keep a proper $\mathrm{OD}_{600} /$ cell density proportionality, be also aware that it is important to dilute the cell culture before the spectrophotometer measurement so that $\mathrm{OD}_{600}$ values do not exceed $c a .0 .3$ (higher values are underestimating the actual cell density).

6. Commercial vectors from the pPICZ series (Life Technologies) do not contain the HIS4 auxotrophy marker and the geneticin resistance gene present on the pPIC9K vectors. They comprise instead a single resistance marker to zeocin antibiotic. In this case, positive transformants are isolated on YPD plates containing a low zeocin concentration (e.g., 25 $\mu \mathrm{g} / \mathrm{mL}$ ) before proceeding to the screening of expressing clones.

7. Direct selection of transformants on geneticin-containing medium is not recommended. Indeed, the level of resistance is dependent on the cell density and false-positive clones may be isolated. In addition, high concentration of antibiotics applied directly after transformation may eliminate potentially valuable clones that have not fully recovered from electroporation nor achieved homologous recombination.

8. Because of its mutations conferring protease deficiencies, the strain SMD1163 exhibits a relatively high susceptibility to geneticin and the concentration range of antibiotic should be reduced to $50-250 \mu \mathrm{g} / \mathrm{mL}$. When using other strains, recombinant clones may be selected on YPD plates supplemented with up to $2 \mathrm{mg} / \mathrm{mL}$ geneticin.

9. When using vectors from the pPICZ series, zeocin concentrations ranging from 25 to 1500 $\mu \mathrm{g} / \mathrm{mL}$ may be applied.

10. This second procedure enables to screen a high number of transformants within a shorter time frame. However, for difficult-to-express membrane proteins, a combination of both methods can be beneficial (e.g., a Yeastern Blot performed with clones selected on high geneticin concentrations).

11. This protocol can be applied to larger culturing format. It is however recommended to maintain a 1:5 ratio between the volume of the culture and the total volume of the selected baffled flasks for an optimal aeration of the culture. Robust procedures for large-scale culturing in biorectors are also available [12] but are less straightforward to handle as they necessitate specific equipment and a succession of culturing conditions before the induction step.

12. BMMY induction medium can be supplemented with different components depending on the protein expressed. In particular, dimethyl sulfoxide (DMSO) supplemented at $2.5 \%$ $(\mathrm{v} / \mathrm{v})$ has been shown to increase remarkably the production yield of ligand-binding active GPCRs [7]. Similarly, adding a ligand specific to the receptor to be produced has been highly beneficial for a large majority of the GPCRs tested [7], probably playing the role of a pharmacological chaperone [13].

13. It is usually not recommended to boil membrane protein samples prior to electrophoresis. 
When compact and highly hydrophobic proteins such as GPCRs are boiled, they usually aggregate and keep stuck in the eoncentratingstacking gel.

\section{References}

1. Gellissen G (2000) Heterologous protein production in methylotrophic yeasts. Appl Microbiol Biotechnol 54(6):741-750

2. Cereghino JL, Cregg JM (2000) Heterologous protein expression in the methylotrophic yeast Pichia pastoris. FEMS Microbiol Rev 24:45-66

3. Sarramegna V, Talmont F, Demange P, Milon A (2003) Heterologous expression of G-proteincoupled receptors: comparison of expression systems from the standpoint of large-scale production and purification. Cell Mol Life Sci 60(8):1529-1546

4. Alkhalfioui F, Logez C, Bornert O, Wagner R (2011) Expression systems: Pichia pastoris. In: Robinson AS (ed) Production of membrane proteins-strategies for expression and isolation. Wiley-VCH, Weinheim. doi: 10.1002/9783527634521

5. Bill RM (2014) Playing catch-up with Escherichia coli: using yeast to increase success rates in recombinant protein production experiments. Front Microbiol 5:85

6. Bertheleme N, Singh S, Dowell S, Byrne B (2015) Heterologous expression of G-protein-coupled receptors in yeast. Methods Enzymol 556:141-164

. André N, Cherouati N, Prual C, Steffan T, Zeder-Lutz G, Magnin T, Pattus F, Michel H, Wagner R, Reinhart C (2006) Enhancing functional production of G protein-coupled receptors in Pichia pastoris to levels required for structural studies via a single expression screen. Protein Sci 15:1115-1126

8. Magnin T, Fiez-Vandal C, Potier N, Coquard A, Leray I, Steffan T, Logez C, Alkhalfioui F, Pattus F, Wagner R (2009) A novel, generic and effective method for the rapid purification of G proteincoupled receptors. Protein Expr Purif 64(1):1-7

9. Bornert O, Møller TC, Boeuf J, Candusso MP, Wagner R, Martinez KL, Simonin F (2013) Identification of a novel protein-protein interaction motif mediating interaction of GPCR-associated sorting proteins with G protein-coupled receptors. PLoS One 8(2):e56336

10. Logez C, Berger S, Legros C, Banères JL, Cohen W, Delagrange P, Nosjean O, Boutin JA, Ferry G, Simonin F, Wagner R (2014) Recombinant human melatonin receptor MT1 isolated in mixed detergents shows pharmacology similar to that in mammalian cell membranes. PLoS One 9(6):e100616

11. Logez C, Alkhalfioui F, Byrne B, Wagner R (2012) Preparation of Pichia pastoris expression plasmids. Methods Mol Biol 866:25-40

12. Singh S, Gras A, Fiez-Vandal C, Martinez M, Wagner R, Byrne B (2012) Large-scale production of membrane proteins in Pichia pastoris: the production of $\mathrm{G}$ protein-coupled receptors as a case 
study. Methods Mol Biol 866:197-207

13. Bernier V, Bichet DG, Bouvier M (2004) Pharmacological chaperone action on G-proteincoupled receptors. Curr Opin Pharmacol 4(5):528-533 